\title{
0 destino do fait divers: política, risco e ressentimento no Brasil contemporâneo*
}

\begin{abstract}
RESUMO
Através dos conceitos de risco e negligência, crimes, acidentes e catástrofes são hoje construídos como dependentes de decisões políticas. Essa forma de construção, de um lado, explica porque parte do que antes era tido como fait divers torna-se notícia política, econômica ou científica. De outro lado, ao menos no Brasil, essa construção opera uma distribuição entre indivíduos comuns inocentes e políticos ineficientes e corruptos, distribuição que alimenta a indignação moral e amplia a crise da política.
\end{abstract}

\author{
PALAVRAS-CHAVE \\ fait divers \\ risco \\ política
}

\section{ABSTRACT}

Through the concepts of risk and negligence, contemporary cultures construct accidents, crimes and catastrophes as depending upon political decisions. On one hand, this construction explains why what used to be considered as fait divers is today viewed as political, economic or scientific news. On the other hand, at least in Brazil, this construction operates a moral distribution between regular, innocent individuals and incompetent, corrupt politicians. This distribution feeds moral indignation and increases the crisis of politics.

\section{KEY WORDS}

fait divers

risk

politics
No final de 2007, o jornal eletrônico Globo Online fez sua retrospectiva dos principais acontecimentos do ano. Para abrigar a interatividade tão valorizada na Internet, a lista era maior do que o habitual, com 35 eventos. A escolha dos leitores restringiria a lista para a extensão tradicional dos "10 mais". Se um indivíduo da década de 1960 do século passado fosse subitamente jogado em nosso presente e descobrisse a retrospectiva, ficaria surpreso com a relativa ausência de acontecimentos "sérios" no ano de 2007: dos selecionados, ao menos 17 tinham como conteúdo crimes, catástrofes naturais, acidentes e esquisitices - isto é, aquilo que outrora era pensado como fait divers, notícias relegadas a seções limitadas dos jornais "de qualidade" ou apropriadas à imprensa "popular"1.

Se o viajante fosse um antropólogo, questionaria seu juízo sobre a frivolidade do diferente e investigaria os critérios de seriedade dos "nativos". Ao pensar que a significação dos acontecimentos depende de regras culturais, o viajante abandonaria sua percepção inicial de que houve poucos eventos políticos, econômicos e científicos importantes e estudaria nossa cultura supondo que talvez tenham mudado os critérios através dos quais repórteres e editores definem o que são essas rubricas tradicionais. Opera, então, com a possibilidade de que muitos acontecimentos que ele considera como fait divers passaram para o âmbito das notícias relevantes para a cidadania.

Sem o conforto da resposta pronta de que houve uma multiplicação do número e da seriedade de crimes, acidentes e catástrofes, olhemos nosso presente com as lentes do passado e nos perguntemos por que esses eventos se tornaram importantes para nossa compreensão do que são a política, a economia e a ciência. Por paradoxal que possa parecer à primeira vista, a proporção elevada na lista do Globo Online revela o estreitamento dos critérios que qualificam uma notícia como fait divers. Sob outro ponto de vista, a proporção elevada deriva de uma mudança conceitual profunda no que várias culturas ocidentais hoje presumem ser o poder da ação humana. De fato, cada vez mais crimes, catástrofes e acidentes são concebidos como tendo sua existência dependente de escolhas, só que agora sem a mediação da atividade de seres extra-humanos, quando estes castigavam nossa imoralidade através de terremotos, erupções vulcânicas, furacões e pragas.

Parte do que antes era tido como fait divers torna-se o cerne da política contemporânea. A contrapartida desse novo vínculo entre, de um lado, a política e, de outro, acidentes, catástrofes e crimes é a transformação na relação entre representantes (políticos) e representados. Essa

paulorgvaz@uol.com.br 
transformação tanto coloca o foco na provável imoralidade dos representantes, quanto institui a garantia de oportunidades para que cada indivíduo desfrute de uma vida longa e prazerosa como a tarefa maior de construção coletiva do futuro pela política. Ao lado do grande número de acontecimentos outrora tidos como fait divers, também indica uma mudança no poder presumido da ação humana o fato de a lista do Globo Online incluir, nos acontecimentos políticos, dois casos de corrupção e o fim de um imposto.

Considerar a seleção feita pelo jornal Globo Online como sintoma de mudança cultural é um modo específico de constituir signo. Em si mesma, uma retrospectiva é banal, igual a tantas outras, e certamente esquecida pela maior parte dos leitores, nem que seja pela renovação anual.

A partir do que, então, constituí-la como signo de uma mudança naquilo que talvez melhor singularize uma cultura, seu modo próprio de presumir o poder da ação humana?

Crimes, acidentes e catástrofes são sofrimentos. Quando a atenção social se fixa num dado sofrimento, cabe perguntar por que precisamente ele, quando tantos outros seriam passíveis de destaque. Por mais imenso que seja para um indivíduo ou uma coletividade, não é natural sua passagem de questão privada a questão pública, a um tema que é de interesse de todos e em relação ao qual algo deve ser feito.

Por que são esses sofrimentos, hoje, que se tornam questões sociais? Ou, numa formulação que realça a dimensão política, por que a preferência midiática por um tipo de vítima?

Para constituir como sintoma a raridade histórica dos sofrimentos, para analisar uma mudança cultural sob o prisma do poder presumido da ação humana, o foco não incide apenas na preferência por tipos de vítimas; recai ainda sobre os diferentes modos de atribuição de responsabilidade (Gusfield, 1981, p. 13-4). A existência desses sofrimentos depende ou não de ações humanas? E se depende, de quem e de que forma? Na sociedade contemporânea, a mídia é um lugar privilegiado de percepção dessas construções causais, pois nela predomina a moralidade de senso comum.

Para desdobrar a constituição de mudança no conceito de fait divers como signo de mudança cultural, discutirei, primeiro, a consagrada conceituação feita por Barthes ainda na década de 60, indicando a distância histórica no modo diferente com o que a mídia hoje iria construir a causalidade em alguns de seus exemplos. A seguir, apresento o conceito de causa no Direito, realçando o nexo entre o conceito jurídico de negligência e o conceito de risco, que seria o termo hoje usado por várias culturas ocidentais para presumir o poder da ação humana.

No final, discutirei algumas razões para que a indignação seja um sentimento tão relevante na política brasileira.

\section{Fait divers, então}

Barthes recusa a definição privativa de fait divers, onde ele é resto, é o que não seria política, economia, ciência e artes. Também seria simplificador afirmar, por diferença exterior, que a separação entre fait divers e as outras seções da mídia remete às oposições entre popular e erudito e entre o jogo e o sério. O necessário é uma conceituação interna; como se trata de texto, uma conceituação a partir da estrutura narrativa.

\section{0 acontecimento é tido como necessário, por mais sofrimento que tenha provocado, os indivíduos suportam e seguem com a vida.}

As notícias de política, economia, ciência e artes têm uma estrutura aberta, são uma informação parcial; a compreensão de um evento noticiado remete a uma narrativa que o precede e que o sucederá (Barthes, 1977, p. 264). O evento ganha sentido no interior dessa narrativa maior. Como Barthes propôs a conceituação na década de 60, essa narrativa que precede é a história, uma história de progresso, onde se narra como os homens cada vez mais conseguem controlar a natureza e estão prestes a, de uma vez por todas, mudar a sociedade, reduzindo ou evitando os sofrimentos que decorrem da precariedade do conhecimento, do apego a superstições e da existência de regras sociais injustas. A história de progresso delimitava o poder presumido da ação humana; diríamos agora que os indivíduos então tinham fé, acreditavam no que não acreditamos mais, na tecnologia e na revolução, quando alimentavam a crença na idéia de sofrimentos evitáveis.

O fait divers, por sua vez, seria uma informação completa, imanente; tudo o que é preciso para compreendêla está dado na própria notícia (Barthes, 1977, 265). Essa imanência só é possível se a estrutura narrativa for fechada e contiver ao menos dois elementos cuja relação provoca espanto, surpresa. O fait divers é um signo, mas misterioso. E a relação primordial entre dois elementos postos em função é a de causa e efeito (Barthes, 1977, 267). Uma primeira forma de haver espanto é a causalidade presente, mas decepcionante, quando não há proporcionalidade entre a fragilidade da causa e o tamanho do efeito, quando uma mulher mata seu amante não por ciúme, mas porque discordavam na política, ou quando um inglês entra para a legião estrangeira, não porque perdeu tudo e nada mais tenha a perder, mas porque não quis passar o natal com a sogra (Barthes, 1977, p. 269,270 ). Uma causa designada, mas que parece insuficiente, é misteriosa porque levanta a suspeita de que 
outra causa, circulante, desde sempre já aí, deveria estar presente para produzir o efeito. Um trem descarrilou no Alasca quando um veado bloqueou o controle das linhas (Barthes, 1977, p. 270); mas um trem não arrasta carros sem sair dos trilhos? Como um animal tão frágil conseguiu provocar o acidente de algo tão gigantesco? $\mathrm{E}$ por que estava ali, naquele momento? Quem ou o quê o colocou na linha do trem? Por quê?

A outra forma de relação misteriosa entre causa e efeito é a coincidência. Como temos a tendência de pensar que o acaso distribui, mas não repete, haverá suspeita de causa no casual se houver repetição (Barthes, 1977, p. 271). O que pensar, senão que há azar, quando uma joalheria for assaltada três vezes ou que, por coincidência, uma setuagenária é assassinada exatamente quando alugou uma casinha para ter uma renda vitalícia (Barthes, 1977, p. 271, 273). Tanta má sorte de inocentes talvez seja ocasião de adivinhar o divino, de supor a atividade de outro agente, insondável, com razões que a própria razão desconhece, mas justo e sempre atuante.

Em alguns casos, entrevemos sua sabedoria; não haveria desígnio se uma fábrica de maçaricos tem seu cofre forte arrombado por ladrões? Aqui se faz, aqui se paga. "Um deus ronda o fait divers", ou ainda, "a causalidade do fait divers é constantemente submetida à tentação da coincidência e, inversamente, a coincidência é constantemente fascinada pela ordem da causalidade" (Barthes, 1977, p. 275).

Barthes, portanto, conceitua o fait divers a partir de três oposições principais: entre estrutura aberta e estrutura fechada, entre continuidade da narrativa e presença intempestiva do sempre aí e entre plano humano da história e plano do divino. O fait divers se dá como espanto e irrupção pela vacância de Deus da esfera pública e da ordem regular da natureza. Desse modo, se mudar aquilo que uma cultura presume ser o poder da ação humana, muda o domínio do espantoso.

Estimemos a distância histórica pela mudança na interpretação de eventos semelhantes aos selecionados por Barthes. Quando algo ou alguém é roubado diversas vezes, esta é a ocasião de denunciar a violência e a impunidade que imperam numa cidade ou país; se uma idosa inocente for brutalmente atacada ou crianças violentadas e assassinadas, esses eventos produzem mudanças na legislação penal em diversos países do mundo. E se um trem descarrilasse hoje porque um animal estava no trilho, as questões colocadas na notícia seriam diferentes e explícitas: não deveria haver reserva ecológica ou, se houvesse, por que atravessá-la com uma linha de trem? Os trilhos não deveriam estar cercados e as cercas serem altas o suficiente e com manutenção adequada? A má sorte que requeria suspeitar do divino é hoje vista como resultado da incúria humana.

O deslizamento de terra que, após chuvas intensas, fechou uma galeria do túnel Rebouças foi selecionado como um dos 35 eventos importantes de 2007 pelo Globo Online. O texto explicando as razões da seleção começa por uma estrutura de fait divers, ao notar que foi no mês em que faria quarenta anos de sua inauguração que o túnel ficou fechado por cinco dias, talvez para lembrar como é importante para a cidade. Mas o texto da retrospectiva não insinuou que foi alguma imoralidade dos cariocas a responsável por dias de engarrafamento, nem deixou em aberto a interpretação do evento: mesmo com a chuva, o deslizamento não teria ocorrido se não houvesse culpa, seja do governo do Estado (tubulação rompida, que a CEDAE não consertou), seja da prefeitura (a GEO-RIO falhou na contenção de encostas), seja uma falha de ambas as instâncias executivas. Se Deus quis significar alguma coisa com o fechamento da galeria, indicou aos cariocas a incompetência de seus governantes, o que, convenhamos, não sugere Sua excepcionalidade: nos últimos anos, nada parece mais regular na mídia brasileira do que denúncias de incompetência, descaso e corrupção.

Uma interpretação não foi enfatizada. Seria possível dizer que deslizamentos acontecem, que às vezes as chuvas são tão intensas que nada pode ser feito, que estamos diante de mais um episódio da relação conflituosa do homem com as forças naturais. Contudo, se é suposta a possibilidade de um evento estar na esfera do poder da ação humana, não investigar a responsabilidade dos homens pelo sofrimento e dizer, inversamente, que acontecimentos dessa natureza fazem parte da ordem do mundo ou é desculpa dos governantes, ou é alienação dos governados. O próprio Barthes escreveu em outro lugar que o procedimento da ideologia é transformar o que é histórico em natural, o que é mutável em algo que pertence à ordem imutável das coisas. Mas pode haver ressentimento, "ideologia", no modo como uma cultura concebe a idéia de sofrimento evitável.

O sentimento coletivo também é diferente. Se o acontecimento é tido como necessário, por mais sofrimento que tenha provocado, os indivíduos suportam e seguem com a vida. Se sua origem é humana, mesmo o que antes seria visto como mero incômodo torna-se ocasião para os indivíduos se conceberem como vítimas e ventilarem sua indignação ${ }^{2}$. Aquele observador da década de 60 talvez ficasse surpreendido com a descrição inflamada do sofrimento dos cariocas após o fechamento do túnel: “O trânsito entrou em parafuso. O nó cego transformou em filiais do inferno as alternativas ao Rebouças - o Túnel Santa Bárbara e o Aterro do Flamengo."

É possível, pois, colocar uma questão: estamos diante do que, exatamente? Ou bem nós, hoje, em princípio, já controlamos processos como violência, acidentes e catástrofes, de tal modo que é o descuido o responsável por sua existência, ou bem é uma indignação já constituída o que nos faz sair à cata de eventos para nos sentirmos vítimas e acusarmos os "imorais"? E o que sustenta tanta indignação? O fato de, por princípio, controlarmos, ou o fato de que cada vez mais tudo nos parece estar fora de controle, embora não devesse? Para desdobrar analiticamente essa questão, um caminho é anali- 
sar o modo como atribuímos responsabilidade pelo sofrimento.

\section{A causa no Direito: negligência e ordem idealizada}

Os enunciados causais no Direito se aproximam daqueles do jornalismo, especialmente quando este se dá na forma da denúncia. O que está em jogo é a verdade da afirmação de que, numa dada ocasião, um evento particular foi o resultado de outro evento particular ${ }^{3}$. Esse enunciado banal ganha relevo se pensarmos que, nas ciências da natureza, o objetivo é formular generalizações, descobrir que um evento sempre ou na maior parte das vezes sucede a outro evento. Como se trata do Direito, esses enunciados causais sobre particulares delimitam imediatamente o plano da ação humana, na medida em que se argumenta a atribuição de responsabilidade de algum sofrimento a decisões que infringiram alguma regra moral ou legal.

A construção causal no Direito se depara com dois problemas maiores. O primeiro é a extensão da série causal explicativa de um sofrimento. A dificuldade está em determinar onde parar o processo regressivo de passagem de um condicionado a uma condição (Hart e Honoré, 1985, p. 12). Dito de outro modo, a dificuldade está em separar, de todos os acontecimentos que antecederam o evento a ser explicado, o que é a causa e o que são os antecedentes sem significação para a atribuição de responsabilidade, o que implica propor que a série regressiva se detém no evento considerado causa, ele próprio visto como não-causado. Alguém mata a tiros um indivíduo; se o assassino for uma criança, o recuo do processo causal irá seja até pais que deixam crianças brincar com revólver ou, se não deixam, até o comerciante que vendeu ilegalmente a arma. Seja, por outro lado, um assassino adulto; para matar, era preciso que também tivesse uma arma. Por que não incluir, na narrativa que explica o assassinato, o ato do comerciante que vendeu a arma ao seu bisavô, embora esse evento anterior seja necessário para a existência do evento? Por que nesse caso o processo causal pára no instante em que ele decide atirar? Por que em alguns casos a narrativa recua e, em outros, não?

Percebem-se, em contraluz, os limites do Direito. Para alguns, pode-se recuar indefinidamente na série que passa de condicionado a condição, de efeito à causa (pois toda condição pode, por sua vez, ser vista como condicionada), de tal modo que tudo o que acontece depende de um número indefinido de acontecimentos passados: o mundo está inteiramente presente em cada evento, por insignificante que seja, e, inversamente, cada acontecimento transforma o mundo ${ }^{4}$. Pela co-presença do mundo a cada evento, um sofrimento coloca imediatamente, para aquele que sofre, a questão de sua relação com o mundo - mas não a indignação com um ser humano. Para outros, a série que recua sucessivamente de condicionado à condição termina em um ser onipotente, como faz o personagem Jó, da Bíblia, que, ao experimen- tar sofrimentos, se questiona sobre a justiça daquele que tudo pode - e também para o fait divers, pois objetos, animais e indivíduos podem ser meros instrumentos de Seu desígnio.

Essas duas posições - série indefinida e ser onipotente - marcam o limite do Direito, pois este começa pelo esforço de estabelecer a responsabilidade humana pelo sofrimento. Daí a relevância do ato ilegal ou imoral tido como voluntário; ele estabelece um limite a partir do qual não é preciso mais recuar na série que vai de condicionado a condição.

No exemplo acima, é porque ainda pensamos que os atos de uma criança não são voluntários que recuamos a série para eventos anteriores: pais descuidados ou vendedores de arma inescrupulosos; do mesmo modo, se o assassino é um adulto, não há porque recuar mais - a discussão se limita, posteriormente, a determinar se seu ato foi mais ou menos voluntário, de modo a calcular a punição.

\section{Uma omissão pode ser causa, pode ser a diferença que fez a diferença, na medida em que 0 desvio causal é pensado em relação a uma ordem construída pelos seres humanos.}

O segundo problema no Direito é separar o que é causa do que é mera condição no conjunto de circunstâncias contemporâneas ou sucessivas, todas necessárias para a existência de um evento (Hart e Honoré, 1985, p. 10). Um incêndio devasta uma floresta, destruindo casas e vidas humanas e não-humanas; a questão é saber que princípios autorizam separar o descuido de jogar uma ponta de cigarro acesa na mata e colocá-lo como causa, e supor como meras condições o oxigênio, a seca prolongada, árvores e gramas ressecadas, o vento, etc. Como se trata de enunciados causais sobre particulares e, mais precisamente, de explicar um desvio do curso regular do mundo (o incêndio, no caso), será mera condição tudo o que é necessário para a existência do evento, mas que está presente quando o mundo segue seu curso regular; será causa, por outro lado, a diferença que fez a diferença. Mesmo que a floresta estivesse ressecada e ventasse fortemente no dia, ela não teria incendiado se não fosse a ponta de cigarro acesa. A partir desses casos simples, vemos que a atitude no Direito é correlacionar um sofrimento qualquer, tido como anormalidade, com um ato humano ilegal ou imoral, supondo que se não houvesse o ato desviante, o sofrimento não teria existido. 
Até aqui, a construção de causa no Direito trafega no bom senso; só a questionam filósofos obstinados em encontrar uma alternativa ética à vingança e à culpa e, para tanto, precisam contrariar o que parece ser tão evidente, dizendo que tudo depende de tudo e que vontade livre só foi inventada pelos homens para acusarem a si e aos outros - e se sabe que esses filósofos raramente são populares. O argumento causal se tornará mais complexo quando entra a negligência, especialmente na sua oposição ao acidental - ao que acontece por acaso.

A negligência como causa também tem uma explicação sensata. Se os seres humanos são capazes de controlar um processo natural, é a falha no controle a responsável pelo reaparecimento do efeito. Podemos nos tornar capazes de evitar a fome gerada por uma seca prolongada se armazenarmos alimentos e/ou construirmos reservatórios. Assim, se uma fome ocorrer, a seca de causa torna-se a condição pela qual uma causa humana, a negligência em armazenar e/ou manter, produziu o efeito (Hart e Honoré, 1985, p. 35-6).

Uma omissão pode ser causa, pode ser a diferença que fez a diferença, na medida em que o desvio causal é pensado em relação a uma ordem construída pelos seres humanos. A terra deslizou na galeria do túnel Rebouças ou porque alguém não fez a contenção adequada de encostas ou porque não consertaram uma tubulação furada que afofava a terra. Uma questão imediata é que a ordem humana a partir da qual se define a omissão pode bem nunca ter existido ou não ser a regra num país ou cidade: mesmo que nunca prefeitura alguma tenha contido adequadamente encostas, o que se propõe é que essa contenção deveria existir. A ponta de cigarro acesa é desvio em relação à regularidade do que acontece na floresta; a ausência de manutenção de encostas pode ser desvio em relação a uma ordem humana idealizada.

Se a negligência pode ser definida em relação a uma ordem humana idealizada, o número de acontecimentos considerados como dependentes da ação humana aumenta consideravelmente. A busca pela causa do sofrimento decorre do desejo de concebê-lo como evitável; atribuir a causa à ação humana lança, retrospectivamente, a possibilidade no que aconteceu (além da ação tida como causa, outra ação poderia ter sido feita, a qual evitaria a existência do sofrimento); a outra ação que poderia ter sido feita, por sua vez, pode ser concebida a partir de uma ordem humana idealizada, que mantém relações frágeis com o que existe.

Um caso significativo de como uma ordem ideal é sustentada e sustenta o desejo de conceber um sofrimento como evitável foi o tsunami asiático do final de 2005. As narrativas seculares apoiaram-se na demora da onda gigante de chegar a alguns países para imaginar modos de reduzir o número de mortos (Bauman, 2006, p. 77). Os sistemas de transmissão de informações sobre terremotos não poderiam ter sido mais eficazes? O governo da Tailândia não soube com razoável antecedência do tsunami? Por que não avisou a população? Para não preju- dicar a indústria de turismo? "Políticos inescrupulosos, que não respeitam a vida humana", alguém poderia dizer a partir das reportagens. Mas é difícil saber como reagiríamos diante de um evento tão excepcional; difícil também saber se aprendemos alguma lição, senão a de que, na próxima vez em que estivermos diante de um evento semelhante, acreditaremos mais uma vez que alguma "lição" nos foi ensinada. Também se percebe que, à medida que aumenta o número de sofrimentos que desejamos ser evitáveis, mais moralidade será demandada daqueles cuja ação é presumida ter o poder de evitar esses acontecimentos e mais necessário será conceber os que causam sofrimentos como profundamente "imorais", talvez monstruosos.

\section{Apesar do que desejamos, os sofrimentos cismam em ocorrer e raramente alguém é tão zeloso quanto deveria.}

Daí o mantra tão freqüente nas páginas e telas da mídia brasileira: os políticos são corruptos e traficantes, terroristas, motoristas que bebem e pais que esquecem filhos no carro são muito malvados.

\section{A causa no Direito: acidente, negligência e risco}

Além da idealização da ordem a partir da qual se define a negligência, há um segundo modo, correlacionado, de se aumentar o número de eventos que parecem depender da ação humana. O conceito de negligência restringe fortemente o que se considera acidental. Num primeiro nível, acidental é oposto ao voluntário e é definido pela não-intencionalidade, como quando alguém atira em outro brincando, por pensar que não havia bala no cartucho, ou quando pulamos da cadeira se alguém entra subitamente na sala. No segundo nível, o acidente está oposto à negligência; um ato negligente é aquele que, embora não seja intencional, tampouco é acidental. Daí uma forte redução no número dos acontecimentos considerados casuais, pois comportamento acidental passa a se aplicar apenas aos casos onde o agente não antecipou as consequiências e as consequiências não são aquelas que indivíduos razoáveis esperariam (Hart e Honoré, 1985, p. 152).

Eis o caso tido como exemplar no Direito anglo-saxão para diferenciar negligência de acidente: um empreiteiro, durante uma obra, bloqueia ilegalmente a calçada, forçando pedestres a caminharem pela rua e uma jovem é atropelada; o pai processa o empreiteiro e ganha. $\mathrm{O}$ atropelamento não seria acidental, pois é uma conseqüência antecipável e esperada de se obrigar passantes a caminharem pela rua; de fato, pode ser dito que a negligência do empreiteiro ampliou as chances de o evento 
ocorrer (Hart e Honoré, 1985, p. 167). E quando a negligência se reúne ao risco, os incidentes que podem ser interpretados sob esse ângulo se multiplicam. Um caso famoso ocorreu na França (se bem me lembro) há alguns anos atrás: um indivíduo foi a uma festa, bebeu muito e, ao sair de carro, atropelou alguém; o atropelado processou os donos da festa e foi compensado. O argumento é semelhante ao caso do empreiteiro: deixar que alguém continue bebendo sabendo que irá dirigir ou deixar alguém bêbado sair de sua casa é uma decisão que amplia o risco de acidente.

Outro caso parecido, agora no Canadá, é o de uma mulher que foi a uma festa da empresa onde trabalhava e bebeu muito; saiu e continuou a beber em outros bares; ao decidir, enfim, voltar para casa, bateu de carro e se machucou. Processou e conseguiu que $25 \%$ dos custos hospitalares fossem pagos pela empresa. À diferença do exemplo do assassino que atira em outro, em todos esses casos não é preciso afirmar que o evento não teria ocorrido se não fosse a negligência; basta argumentar que o zelo adequado reduziria as chances de o evento ocorrer.

\section{0 retorno surpreendente da crença de que os sofrimentos resultam da imoralidade dos homens responde pela redução do que pode ser fait divers.}

Em suma, o ato negligente cria ou deixa existir condições a partir das quais um evento ocorre e provoca sofrimentos, não importando se o evento é natural (como a chuva que faz encostas deslizarem) ou um ato humano (como o atropelamento), voluntário ou não. $\mathrm{O}$ que se debate juridicamente é a razoabilidade de uma série causal conectando um ato negligente, imoral ou ilegal, a um dano, sabendo que há um evento interveniente entre os dois termos da série, evento que foi o responsável direto pelo dano.

Apesar do que desejamos, os sofrimentos cismam em ocorrer e raramente alguém é tão zeloso quanto deveria. Assim, em tudo o que ocorrer e que desejamos não ter ocorrido, será possível pensar que uma instância reguladora, cuja ação teria maior poder do que a de indivíduos comuns, era capaz de controlar o comportamento daquilo ou daqueles que causam sofrimento. Princípio amplo de explicação, mas que, no Direito, tem sua validade sempre contestada pela singularidade de cada caso. Voltemos ao motorista que saiu bêbado da festa; talvez naquela noite estivesse chovendo muito e que, imediatamente antes do atropelamento, um pneu estourou. Seu advogado argumentará que qualquer motorista teria perdido o controle do carro.
Se o princípio da negligência passa a ser utilizado na mídia, sua aplicação pode não encontrar resistência. Para que um evento apareça nas páginas e telas dos meios de comunicação de massa, ele deve interessar amplamente. Um modo de generalizar é tornar um incidente uma incidência, torná-lo instanciação de um problema maior que o antecede e que o sucederá, se nada for feito. Despido de sua singularidade, cada evento pode ser explicado pelo princípio, ainda mais no caso da mídia brasileira, onde praticamente não há notícias sobre o sistema judiciário (não estamos acostumados a escutar argumentos que questionam a validade da aplicação do princípio) e onde a verdade segue cada vez mais o modelo da denúncia: o discurso contrário à aplicação do princípio já aparece como suspeito, pois é a fala interessada do acusado.

Após semanas discutindo se a demora do governo em inserir micro-ranhuras na pista de Congonhas poderia ser ou não caracterizada como negligência que contribuiu para a queda do avião da TAM (um evento da lista), parte da mídia brasileira dedicou-se a acidentes de carro (outro evento que constava da lista), talvez porque aí se tenha uma oferta constante de sofrimentos a municiar as denúncias de violação de regras morais. Em resposta ao destaque, no final do ano o Ministério da Justiça apresentou uma nova legislação que proíbe a venda de bebidas alcoólicas à beira de estradas e amplia a pena para quem dirige embriagado. Pela resposta, adivinha-se como a mídia transformou cada acidente de carro singular em uma incidência: a legislação permissiva foi o "dono da festa" para diversos acidentes.

Nas notícias de crime, também a legislação permissiva é imputada como negligência a contribuir para sofrimentos ocorridos e a vir. No caso da morte do garoto João Hélio (outro evento da lista), muitos falaram e escreveram sobre a necessidade de reduzir a maioridade penal e instituir a pena de morte diante da enormidade do crime, para que algo assim não se repetisse.

Não adianta apontar que já houve um caso semelhante nos Estados Unidos em 1992, quando uma professora universitária, Pamela Basu, durante o roubo do seu carro, foi morta ao ser arrastada centenas de metros pela rua por ficar presa no cinto de segurança - enquanto era arrastada, gritava desesperada para não matarem sua filha de menos de dois anos que estava dentro do veículo (Gup, 1992). Não adianta propor que sofrimentos terríveis podem ocorrer pela coincidência entre design dos carros e pequenas sordidezes (essas que muitos cometemos ao longo da vida) de alguns e desespero de outros. É mais simples explicar o sofrimento incompreensível pela enormidade da maldade de alguns - e desejar puni-los exemplarmente.

E tanto aqui como lá, a legislação permissiva foi destacada como negligência no conjunto de circunstâncias que antecederam o evento; nos Estados Unidos, um dos assaltantes tinha acabado de sair em liberdade condicional da pena por tráfico de heroína. 


\section{Generalizando, será tido como "bom" o indivíduo tolerante e que sabe cuidar da vida, sua e dos outros.}

O drama criminal constantemente reencenado no Brasil não é, contudo, o da lei que assegura o funcionamento da sociedade, não é o julgamento justo de criminosos, mas a ação policial que deveria proteger os inocentes. Assim, é comum as notícias notarem que um dado crime ocorreu a 50, 100, 200 ou 300 metros de uma cabine ou delegacia de polícia. Não se trata de informação necessária à localização do evento, mas da indicação de negligência, não daquela que recomenda a policiais o cuidado com o uso de armas diante de inocentes, mas daquela que lamenta que a polícia não consiga impor sua "força".

Por mais aleatório que tenha sido o crime, a "informação" propõe que se a polícia intimidasse os bandidos ao invés de estar intimidada, se não deixasse os crimes ocorrerem na sua frente e se não estivesse em conluio com os criminosos (Vaz et alli, 2005), em suma, se a polícia fosse composta apenas por integrantes do BOPE tal como ficcionalizado pelo filme Tropa de Elite (outro evento da retrospectiva), os sofrimentos não existiriam.

Essa informação sobre a proximidade da polícia aparece mesmo se a notícia estiver ao lado ou na seqüência de outra sobre tiroteio entre policiais e infratores que feriu ou matou indivíduos comuns. Considerar como negligência não impor e demonstrar a "força" sobrepuja qualquer consideração de cuidado com indivíduos, especialmente se fazem parte das "classes perigosas", os pobres (Reis, 2005, p. 44). Essa preferência fica clara em operações policiais em favelas, como a do Complexo do Alemão, que resultou na morte de 21 indivíduos (mais um evento da lista). Se os traficantes querem dominar a cidade do Rio de Janeiro, como diz o filme Tropa de Elite logo na abertura, repetindo o que jornais e TVs implícita ou explicitamente afirmam, se estamos em guerra, não há incômodo com a morte de "inimigos" e é preciso se resignar com a existência de "danos colaterais", com o sacrifício de inocentes pelo bem comum, ainda mais se moram em favelas. O que está naturalizado no imaginário da cidade é a guerra, e não a igualdade de Direito entre indivíduos. A legitimidade prévia das mortes em operações policiais é caso transparente do que Nietzsche alertava em relação ao ressentimento: parte da dor do mundo decorre da indignação com a dor do mundo.

\section{Risco e ressentimento}

O retorno surpreendente da crença de que os sofrimentos resultam da imoralidade dos homens responde pela redução do que pode ser fait divers. Uma objeção a essa hipótese lembra o hedonismo vigente; é adequado falar em moralidade, quando o que se recomenda diariamente, especialmente em peças publicitárias, é que cada um tem o direito a ser feliz do seu jeito?

De fato, as culturas ocidentais contemporâneas podem ser caracterizadas pela autenticidade generalizada, pela busca, por cada indivíduo, do que o torna singular e onde, portanto, o princípio do não-dano, formulado por Stuart Mill ainda em meados do século XIX, ganha aceitação social: ninguém tem o direito de interferir na busca singular de felicidade de um indivíduo, a não ser que ele cause dano a outro (Cf. Taylor, 2007, p. 473-504). No nível imediato, não há consenso moral algum sobre a boa vida. No nível reflexivo, porém, ao menos duas regras são formuladas. Por reversibilidade do princípio, se não quero que ninguém interfira na minha vida, não tenho o direito de interferir nas escolhas alheias; portanto, o princípio recomenda a tolerância em relação às diferenças de crença e preferência sexual. Em segundo lugar, se o limite do que se faz é o dano ao outro, a vítima de crimes, acidentes e catástrofes é lugar do consenso moral mínimo (Cf. Boutellier, 2000, p.40-69), assim como será imoralidade causar dano ou colocar o outro em risco. Generalizando, será tido como "bom" o indivíduo tolerante e que sabe cuidar da vida, sua e dos outros. A tolerância e a compaixão pelos inocentes são sentimentos básicos da vida pública nas culturas ocidentais contemporâneas; a contrapartida dessa vigência é a indignação com os preconceituosos, autoritários e, especialmente, com aqueles que, pelos seus atos, não parecem ter compaixão alguma com a vida alheia.

Uma das razões para que o conceito de risco tenha tal preeminência nas culturas ocidentais contemporâneas é sua articulação fácil, sem muitas fricções, com o princípio do não-dano. Para haver risco, é preciso supor que o evento a ser explicado ou calculado dependa de uma dupla contingência: o evento pode ou não existir e, se vier a existir, sua existência será atribuída a alguma decisão, que também pode ou não ser feita (Luhman, 1993, p. 16).

O conceito de risco, por supor uma decisão humana na origem dos eventos, pode ser moralizado. Mas sua moralidade não qualifica previamente uma ação. Um ato não é tido como ruim por ordem divina ou por referência a uma norma social prévia. Com o conceito de risco, a qualificação é reflexiva, como que do exterior, a partir das conseqüências negativas de uma decisão. Define, portanto, uma moralidade utilitária que institui como hesitação uma estranha forma de arrependimento (Luhman, 1993, p. 11). Na forma usual, arrependemonos após a ação ter sido realizada e porque ela infringiu uma regra moral que acatamos.

Com o conceito de risco, o que se propõe é que nos arrependamos antes de fazer, e não por infração de regras prévias, mas pela conseqüência danosa antecipada e calculada. Em relação às conseqüências danosas para um indivíduo, seus prazeres são, ao mesmo tempo, objeto a ser controlado e alvo reafirmado. Como o futuro é 
incerto, tanto as conseqüências danosas antecipadas no presente podem não ocorrer, quanto não sabemos como, no futuro, avaliaremos nossas escolhas presentes. Poderemos nos arrepender tanto de fazer, quanto de não fazer, ao pensarmos que tanto autocontrole impediu que aproveitássemos a vida; o melhor, então, é propor um compromisso entre prazeres e riscos, moderando não só o prazer, mas a própria moderação, e deixar que cada um decida o quão arriscado será, para si mesmo, na sua busca da felicidade.

\section{Parece hipocrisia que, numa mesma página de jornal, estejam a denúncia de que um governador teve caso com uma prostituta e a notícia de que indivíduos poderão praticar sexo em praça pública.}

Uma segunda razão para a articulação sem muitas fricções com o princípio do não-dano está na distribuição entre público e privado produzida pelo conceito de risco quando explica os sofrimentos. Na esfera privada, inicialmente, o indivíduo avalia seus prazeres segundo as conseqüências para si e busca um compromisso entre prazeres e risco. Por outro lado, ainda na esfera privada, o risco dimensiona a responsabilidade perante os outros a partir do que o indivíduo consome; como asseguram peças publicitárias no Brasil e no mundo, consumir drogas, por exemplo, não seria problemático se seu consumo não provesse armas para traficantes e terroristas. Esse é um apenas um caso dentre outros onde é proposto o slogan "pense globalmente, aja localmente". A relação com a política é também avaliada pela forma do consumo, como o atesta a reclamação freqüente de que, mesmo pagando tanto imposto, um indivíduo não recebe a segurança a que tem direito. Em suma, o conceito de risco garante ampla latitude na busca de prazeres do indivíduo, permitindo, ao mesmo tempo, que ele se conceba como inocente na sua relação com os outros - o que é uma novidade histórica considerável, pois o prazer, especialmente o sexual, foi designado pelo cristianismo como a origem de nosso descuido com o outro (Brown, 1990, p. 38-64).

Pelo conceito de negligência, o risco também provê um lugar para a ação política, ou melhor, dos "políticos". Ao Estado, cabe impedir que outros nos façam correr um risco que não escolhemos correr, cabe impedir que alguns, inescrupulosos, descontrolados ou sem compaixão, ameacem nossas vidas. E se não impede, o Estado é composto por incompetentes e imorais.
Uma observação de Freud indica um caminho para se pensar porque se exige tanta moralidade dos políticos. Em Moisés e o Monoteísmo, comentando a invenção dos dez mandamentos, Freud afirma que a sabedoria judaica consistiu em inventar regras morais impossíveis de serem cumpridas; desse modo, nunca faltaria alguma imoralidade para explicar qualquer sofrimento que aparecesse: quem não desonra e desobedece aos pais ou não deseja a mulher do próximo? Essa observação nos remete a dois requisitos da prática de explicar o sofrimento por acusação - de si ou do outro. Em primeiro lugar, é necessário haver ampla oferta de atos imorais, é preciso que a atenção moral incida sobre um objeto - o desejo, no caso analisado por Freud - que ofereça muitos casos de imoralidade. Em segundo lugar, quanto maior for a demanda de explicações, quanto mais vulneráveis os indivíduos de uma dada cultura se sentirem, como seria o caso dos judeus em fuga do Egito, maior será o rigor moral.

O Estado, ao menos no Brasil, atende ao primeiro requisito. Se precisarmos de imoralidade ou ineficiência para explicar porque algum sofrimento existe, pelo seu tamanho, pela burocratização, pelo próprio imaginário associado ao funcionário público e à política, será fácil encontrar no Estado casos de corrupção ou incompetência $^{5}$. Em outros países, como nos Estados Unidos, o obstáculo pode ser o governo ou o adversário político. O discurso conservador reitera que os defensores dos direitos humanos e das liberdades individuais impedem ou querem impedir que o governo adote ações apropriadas para a segurança de todos - tortura, detenção indefinida, vigilância telefônica e na Internet, etc. No Brasil, porém, basta o Estado, o que explica a continuidade de sua posição de responsável mor pelos sofrimentos em diferentes administrações.

Já a vulnerabilidade dos indivíduos não é apanágio dos brasileiros ${ }^{6}$. Segundo a descrição de vários sociólogos, cada vez mais a vida coletiva deixa o indivíduo desprotegido, desproteção que está associada à crise da família, dos sindicatos, à redução das redes de segurança em relação à saúde, educação e trabalho providas pelo Estado de bem-estar e à aceleração das mudanças tecnológicas, que torna incerto se algum esforço no presente terá uma recompensa no futuro (Bauman, 2006; Castel, 1999; Garland, 2001). Ao mesmo tempo, cada vez menos o indivíduo se sente capaz de transformar aquilo que afeta sua vida privada, mas que depende da vida em sociedade, incapacidade que está articulada à crise do Estado Nação e da política. Ironicamente, as denúncias de imoralidade ampliam essa vulnerabilidade, pois reforçam a descrença na política.

Embora vulnerável, o indivíduo se supõe no direito à segurança, nem que seja por pensar que, em suas escolhas privadas, sabe cuidar de si e de seus próximos. Uma vez mais, o sentimento de insegurança não remete só aos perigos reais, nem deriva apenas da constatação de que proteções efetivas estão sendo negligenciadas. 
Decorre, também, da distância estimada entre o que existe e o que deveria existir (Castel, 2003, p. 6) e, no caso, entre o valor que o indivíduo atribui ao que faz e o valor que atribui ao que os outros fazem. Se o indivíduo não dispõe mais de canais políticos para que sua ação mude os aspectos da vida coletiva que afeta sua vida privada, nem por isso se torna fatalista. Ao contrário, supõe que alguém deveria poder. Parece hipocrisia que, numa mesma página de jornal, estejam a denúncia de que um governador teve caso com uma prostituta e a notícia de que indivíduos poderão praticar sexo em praça pública. Contudo, é necessário haver, ao mesmo tempo, a inocência dos cidadãos e a imoralidade dos políticos, apesar de uma se parecer muito com a outra. Senão, como acreditar hoje que crimes, acidentes e catástrofes são evitáveis?

\section{0 fait divers, hoje}

Será que não há mais fait divers? Claro que há, mas talvez ele tenha mudado de função e essa mudança seja também sintomática da moralidade hegemônica nas culturas ocidentais contemporâneas. Embora tenha argumentado que a conceituação de Barthes era datada historicamente, mantive seu esquema abstrato que separava, de um lado, estrutura aberta, onde a significação é clara por remeter ao plano da ação humana, e estrutura fechada, de significação misteriosa, que remetia ao plano do divino. Nos últimos anos, pela mudança no poder presumido da ação humana, o plano humano passou a incluir crimes, acidentes e catástrofes. Não que essa ação, mesmo que imaginariamente, possa mais do que antes; são outros sofrimentos que se tornam importantes e evitáveis, enquanto os outrora significativos tornam-se irrelevantes e/ou parte da ordem das coisas - poucos acreditam ser possível recuperar alguns criminosos e muitos acreditam que desemprego e pobreza relativa fazem parte da ordem do mundo, desejada ou não.

De todo modo, hoje, a "má sorte" presente em crimes, acidentes e catástrofes não requer mais a crença em uma justiça superior, embora incompreensível; ela é o resultado claro, sempre detectável, de uma falha humana. São duas estratégias diferentes de escapar da inquietação trazida pela possibilidade de haver acaso. A oposição primária não é entre sentido claro e sentido misterioso, mas entre sentido e ausência de sentido.

Na retrospectiva do Globo Online, havia dois casos irredutíveis de fait divers. O primeiro é o urso que sobreviveu apesar de sua morte ser exigida pelos defensores dos direitos dos animais. O outro caso é a junção de três notícias sobre vidas salvas por heróis improváveis: a criança vestida de super-herói que retira outra de um incêndio; a mãe que, sem saber nadar, impede que sua filha se afogue; a idosa que, mesmo frágil, dá mostra de força surpreendente e socorre familiares. Se má sorte resulta de falha humana, o divino não precisa mais punir aqueles que só nós pensávamos ser inocentes ou escrever certo por linhas tortas quando inocentes sofrem ou morrem. O divino pode só ajudar. Esse ser que não pune, que parece agora indiferente a nossas pequenas gulas e luxúrias, uma figura apenas positiva do pai, talvez o mero oposto dos "políticos", é uma redução antropomórfica do mistério sintomático de culturas marcadas pelo hedonismo light e pela vulnerabilidade wfamecos

\section{NOTAS}

* O autor agradece ao CNPq e à FAPERJ pelo financiamento à pesquisa. Esse texto desenvolve temas apresentados na aula inaugural do Programa de PósGraduação em Comunicação Social da PUC-RS. O autor deseja que o artigo esteja à medida da honraria.

1. A dissertação de Carolina Sá-Carvalho foi quem primeiro observou a singularidade da retrospectiva (SáCarvalho, 2008, p. 146). Na seqüência, listarei, em primeiro lugar, os 17 títulos dos eventos que considerei como podendo ser, anteriormente, classificados como fait divers. Os dois primeiros são fait divers aqui e lá. $\mathrm{O}$ décimo oitavo e o décimo nono talvez devessem ser assim classificados. Por fim, estão os três eventos políticos considerados significativos. Eis a lista: 1) Knut, de ursinho a ursão; 2) Heróis da vida real; 3) Tragédia da TAM; 4) Descontrole aéreo; 5) O buraco do metrô; 6) Al Gore e o meio ambiente; 7) Barbárie nas estradas; 8) O dia em que o Rio parou; 9) Desabamento na Fonte Nova; 10) O fenômeno "Tropa de Elite"; 11) A morte de João Hélio; 12) O sumiço de Madeleine; 13) Massacre no Campus; 14) A classe média no crime; 15) Operações da PF; 16) Recall não é brinquedo, não; 17) Polícia sobe morro; 18) Deu a louca nas celebridades; 19) Chávez não se cala; 20) $O$ Caso Renan; 21) Julgamento do Mensalão; 22) CPMF, a derrota de Lula. A íntegra está disponível em: http:/ /oglobo.globo.com/especiais/retrospectiva2007.

2. Frank Furedi mostra como um mesmo tipo de evento, mortes por inundação no ano de 1953 e no ano de 2000, provocou diferentes reações dos ingleses. Em 1953, quando a inundação matou 307 pessoas, a reação foi reafirmar que os ingleses suportariam dias difíceis. Em 2000, quando 12 morreram, o comentário predominante era afirmar que, além dos mortos, muitos passariam a sofrer de estresse pós-traumático, que sofreriam por ter sofrido. Em 2000, a origem da catástrofe foi atribuída aos políticos e a diversas agências governamentais. Cf Furedi, 2006, p. 17-18.

3. Estarei seguindo, nas próximas páginas, o esplêndido livro de Hart e Honoré sobre a causalidade no Direito. A preocupação dos autores é a fundamentar o Direito por mostrar que o conceito de causa aí utilizado é o mesmo que aquele usado pelos homens comuns. Evidentemente, os autores não concordariam com a desconstrução dessa causalidade feita por este artigo. 
4. Essa relação entre modo de conceber uma série regressiva, causalidade, livre-arbítrio e ordem natural foi baseada nas antinomias do mundo, descritas por Kant na Crítica da razão pura.

5. Nas pesquisas realizadas na década de 90 com membros da elite no Brasil, Elisa Reis observou que mesmo políticos e administradores de estatais responsabilizavam a ineficiência do Estado pela persistência do problema da pobreza no Brasil. Cf Reis, 2005, p. 40-1.

6. Mary Douglas associou a preeminência do conceito de risco com a vulnerabilidade dos indivíduos gerada pela globalização. Embora esteja na continuidade das noções de tabu e pecado, a função do conceito de risco é outra. Não se trata mais de explicar danos coletivos pela falha moral de indivíduos comuns, mas de explicar danos a indivíduos comuns pela falha dos "poderosos". Cf Douglas, 1992, p. 22-37.

\section{REFERÊNCIAS}

BARTHES, R. (1977). Ensaios críticos. Lisboa: Edições 70.

BAUMAN, Z. (2006). Liquid fear. Londres: Polity Press.

BOUTELLIER, H. (2000). Crime and morality. Dordrecht : Kluwer Academic Publishers.

BROWN, P. (1990). Corpo e sociedade: o homem, a mulher e a renúncia sexual no início do cristianismo. Rio de Janeiro: Jorge Zahar Editor.

CASTEL, R. (2003). L'insecurité sociale. Paris: Seuil. (1999). As metamorfoses da questão social. Petrópolis: Vozes.

DOUGLAS, M. (1992). Risk and blame. Londres: Routledge.

FUREDI, F. (2006). Culture of fear revisited: risk-taking and the morality of low expectation. Londres: Continuum.

GARLAND, D. (2001). The culture of control. Chicago: The University of Chicago Press.

GUP, T. (1992). A savage history. In Time Magazine, 9/21. Disponível em: http:/ / www.time.com/time/magazine/article/0,9171,976504,00.html. Acessada em março de 2008 .

GUSFIELD, J.R. (1981). The culture of public problems: drinking-driving and the symbolic order. Chicago: Chicago University Press.

HART, H.L.A. e HONORÉ, T. (1985). Causation in the
Law. Oxford: Oxford University Press, 2 ed.

LUHMAN, N. (1993). Risk : a sociological theory. New York: A. de Gruyter.

KANT, I. (1979). Crítica da razão pura. São Paulo: Abril Cultural.

REIS, E. (2005). Perceptions of poverty and inequality among Brazilian Elites. In Elisa Reis e Mick Moore (org.). Elite perceptions of poverty and inequality. Nova Iorque: Zed Books.

SÁ-CARVALHO, C. (2008). O sofrimento em imagens: uma história entre a fotografia e a política. Dissertação de mestrado. ECO/UFRJ. Mimeo.

TAYLOR, C. (2007). A secular age. Cambrige, Ma: Harvard University Press.

VAZ, P.,SÁ-CARVALHO, C. e POMBO, M. (2005). Risco e sofrimento evitável: a imagem da polícia no noticiário do crime. E-compós - Revista da Associação Nacional dos Ppg em Comunicação, n. 4, pp. 1-22. 